Journal Of Al Azhar University Engineering Sector

Vol. 11, No. 39, April 2016, 469-480

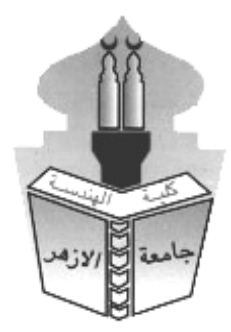

\title{
NON LINEAR FINITE ELEMENT ANALYSIS FOR NORMAL AND HIGH STRENGTH CONCRETE COLUMNS CONFINED BY RECTANGULAR TIES
}

\author{
Mohamed Abdelzaher Mohamed Shanan', Ahmed Ragaey Hasan Anis ${ }^{2}$, Ashraf Hasan \\ El-Zanati ${ }^{2}$ and Kamal Ghamry Metwally ${ }^{2}$ \\ ${ }^{1}$ M.Sc. in Structural Engineering, Faculty of Engineering, Cairo University, \\ Prof. Dr. Ahmed Ragaey Hasan Anis ${ }^{2}$ and \\ ${ }^{2}$ Reinforced Concrete, Structural Engineering, Department, Faculty of Engineering, Cairo \\ University
}

\begin{abstract}
This paper presents a nonlinear finite element analysis of normal and high strength reinforced concrete columns confined with rectangular ties under axial compressive loading. The paper presents a nonlinear finite element analysis for nineteen normal strength concrete rectangular columns with different concrete dimensions, different concrete strength and confinement characteristics. These specimens were tested by the author and a set of another twenty high strength concrete square columns were tested by other researchers. ANSYS 15 Finite Element Software was used in this study. Concrete was modeled with eight nodes SOLID 65 element that can be translated either in the $\mathrm{x}, \mathrm{y}$ and $\mathrm{z}$ axis directions. Longitudinal and transverse reinforcement were modeled as discrete element using 3D-link 180 element type. The nonlinear requirements for each material were implemented in the modeling. The results indicated that the axial force - axial strain relationship obtained from the analytical model using ANSYS are closely matched with the experimental data. The comparison shows that the ANSYS is capable of modeling and predicting the actual nonlinear behavior of confined normal and high-strength concrete columns under concentric loading. The maximum applied load and the maximum strain have also been confirmed to be satisfactory. Depending on this agreement between the experimental and analytical results, a parametric numerical study can be done by ANSYS 15 to clarify and evaluate the effect of confinement variables on the strength of normal and high strength reinforced concrete columns confined with rectangular ties under axial compressive loading.
\end{abstract}

\section{KEYWORDS: ANSYS, Strength; Confinement; nonlinear finite element analysis; Nonlinear behavior.}

\section{INTRODUCTION}

Current design of reinforced concrete structures is concerned with the behavior of ultimate strength and ductility under severe loading condition in view of the safety of structures and economy. Columns are considered as one of the most important structural elements which play a significant role in the structural design, and they are basically considered as the main structural elements used to resist both vertical and lateral loads, while the importance of ductility and associated energy absorption capacity of a structure in resisting earthquakes has long been recognized. The need for ductility was emphasized in recent years in light of the damages sustained by ductile buildings subjected to severe earthquakes. The previous researches have shown that the required ductility can be attained easily if the member behaves 
essentially in the flexure mode. Compression failure in reinforced concrete members is recognized as a brittle failure. It is evident that special design and detailing techniques must be employed to improve ductility of a column, which is a compression member. Previous researches have demonstrated that confinement of concrete column improves both the strength and ductility very significantly. In spite of a lot of researches that studied the stressstrain relationship and ductility of confined concrete columns, more investigation, especially for rectangular columns are needed. The overall objective of this paper is to present a nonlinear finite element analysis for a group of tested specimens of normal and high strength reinforced concrete columns confined with rectangular ties which have different concrete strength and confinement characteristics with good agreement with the experimental results. So, a parametric numerical study can be conducted by ANSYS 15 Finite Element Analysis to clarify and evaluate the effect of new values of variables on strength and ductility of the columns.

\subsection{Properties of columns specimens tested by the author :}

The properties of columns are indicated below in table (1), while the cross sectional arrangements and section geometry of tested columns are indicated below in Fig. (1).

Table 1: Properties of Columns specimens tested in this study

\begin{tabular}{|c|c|c|c|c|c|c|c|c|c|c|}
\hline \multirow{2}{*}{ 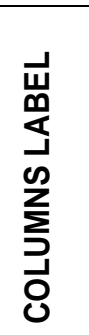 } & \multirow{2}{*}{ 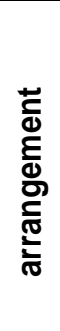 } & \multirow{2}{*}{ 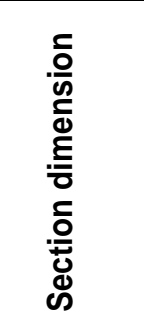 } & \multicolumn{2}{|c|}{$\begin{array}{l}\text { Longitudinal } \\
\text { Reinforcement }\end{array}$} & \multirow{2}{*}{$\frac{f_{c}^{l}}{\sum_{0}^{\frac{\pi}{2}}}$} & \multirow{2}{*}{$\begin{array}{c}f_{\text {y.long }} \\
\text { Mpa }\end{array}$} & \multirow{2}{*}{$\begin{array}{l}\begin{array}{l}\text { fy. } \\
\text { ties }\end{array} \\
\\
\frac{\pi}{2}\end{array}$} & \multirow{2}{*}{ 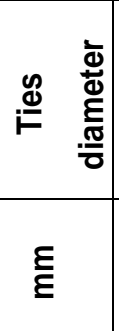 } & \multirow{2}{*}{$\begin{array}{l}\mathbf{s} \\
\mathbf{E}\end{array}$} & \multirow{2}{*}{$\begin{array}{c}\rho \\
\text { ties } \\
\%\end{array}$} \\
\hline & & & 으 & 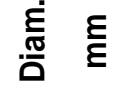 & & & & & & \\
\hline $\mathrm{C}-1$ & 4 & $200 \times 400$ & 12 & 12 & 41.5 & 501 & 331 & 8 & 80 & 2.25 \\
\hline C -2 & 1 & $200 \times 400$ & 4,4 & 10,18 & 41.5 & 534,361 & 331 & 8 & 80 & 1.07 \\
\hline C - 3 & 3 & $200 \times 400$ & 4,4 & 10,18 & 41.5 & 534,361 & 331 & 8 & 80 & 1.48 \\
\hline C - 4 & 3 & $200 \times 400$ & 12 & 12 & 41.5 & 501 & 291 & 6 & 45 & 1.41 \\
\hline $\mathrm{C}-5$ & 2 & $200 \times 400$ & 12 & 12 & 41.5 & 501 & 331 & 8 & 80 & 1.38 \\
\hline C - 6 & 3 & $200 \times 400$ & 12 & 12 & 39.5 & 501 & 331 & 8 & 60 & 1.97 \\
\hline $\mathrm{C}-7$ & 3 & $200 \times 400$ & 12 & 12 & 39.5 & 501 & 331 & 8 & 80 & 1.48 \\
\hline C -8 & 2 & $200 \times 400$ & 4,4 & 10,18 & 39.5 & 534,361 & 534 & 10 & 100 & 1.66 \\
\hline C - 9 & 4 & $200 \times 400$ & 12 & 12 & 39.5 & 501 & 331 & 8 & 120 & 1.50 \\
\hline $\mathrm{C}-10$ & 3 & $200 \times 400$ & 10 & 12 & 39.5 & 501 & 534 & 10 & 125 & 1.42 \\
\hline $\mathrm{C}-11$ & 1 & $200 \times 300$ & 4,4 & 10,18 & 47.5 & 534,361 & 331 & 8 & 80 & 1.21 \\
\hline $\mathrm{C}-12$ & 2 & $200 \times 300$ & 4,4 & 10,18 & 43.5 & 534,361 & 534 & 10 & 100 & 2.14 \\
\hline $\mathrm{C}-13$ & 3 & $200 \times 300$ & 12 & 12 & 43.5 & 501 & 534 & 10 & 125 & 1.60 \\
\hline $\mathrm{C}-14$ & 3 & $200 \times 300$ & 4,4 & 10,18 & 43.5 & 534,361 & 331 & 8 & 100 & 1.37 \\
\hline C-15 & 3 & $200 \times 300$ & 12 & 12 & 47.5 & 501 & 331 & 8 & 80 & 1.67 \\
\hline $\mathrm{C}-16$ & 4 & $200 \times 300$ & 12 & 12 & 43.5 & 501 & 331 & 8 & 80 & 2.47 \\
\hline C-17 & 3 & $200 \times 300$ & 12 & 12 & 47.5 & 501 & 331 & 8 & 50 & 2.67 \\
\hline C-18 & 3 & $200 \times 300$ & 10 & 12 & 43.5 & 501 & 331 & 8 & 80 & 1.67 \\
\hline $\mathrm{C}-19$ & 2 & $200 \times 300$ & 12 & 12 & 43.5 & 501 & 331 & 8 & 110 & 1.79 \\
\hline
\end{tabular}



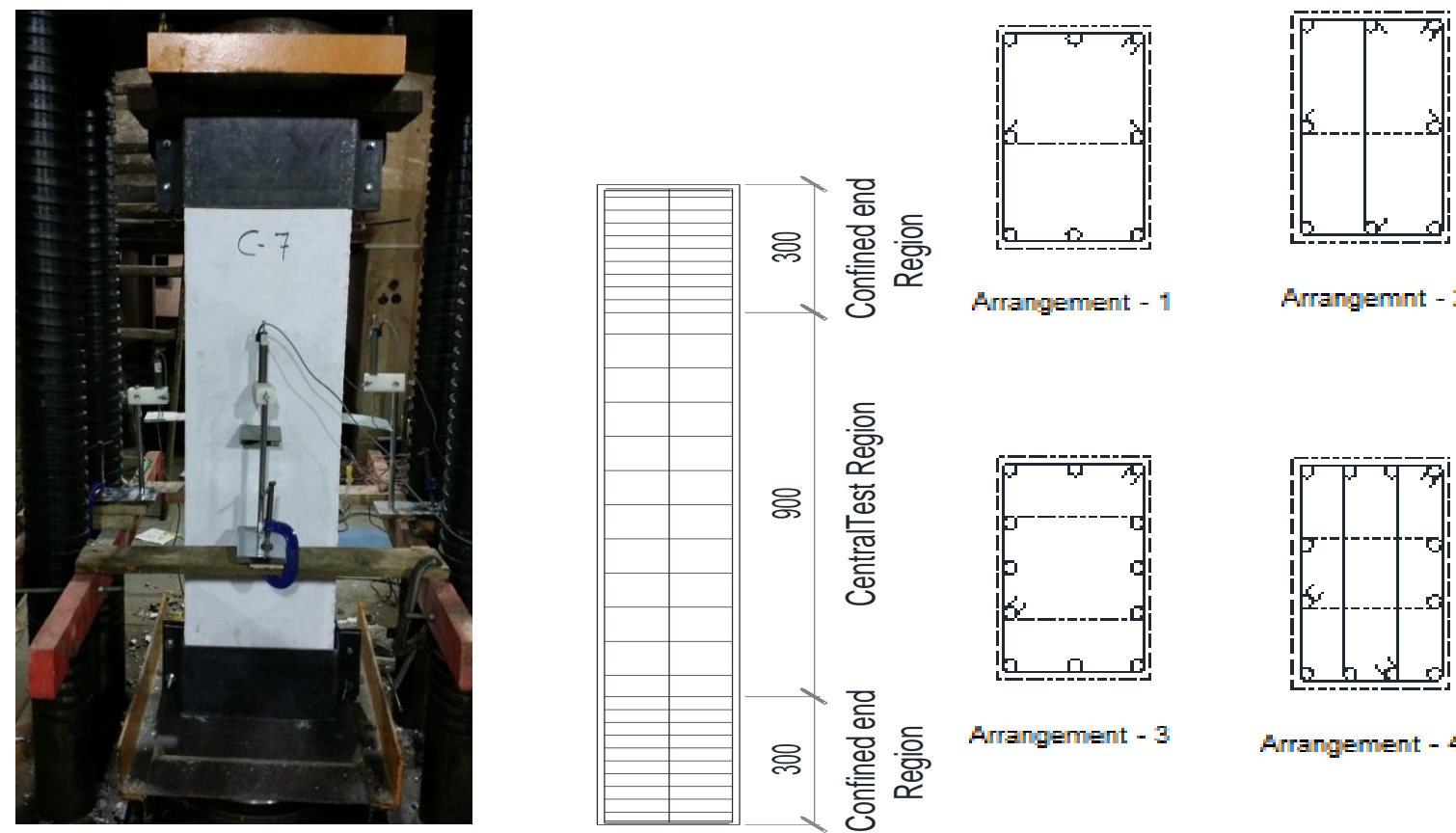

Arrangemnt - 2

8 8. 흥
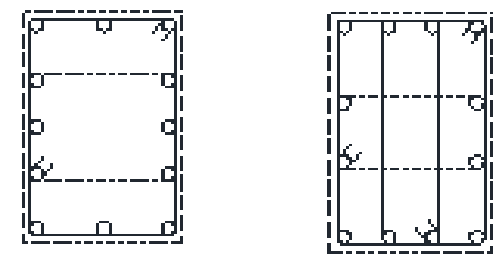

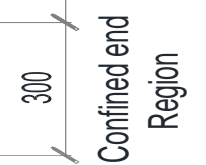

Arrangement -3

Arrangement - 4

Fig. 1: Cross sectional arrangements and section geometry of tested columns

1.2. Properties of columns specimens tested by Razvi and Saatcioglu (1996a) ${ }^{[1]}$ :

The properties of tested columns are indicated below in table (2), while the Cross sectional arrangements and section geometry of tested columns are indicated below in Fig. (2).

Table 2: Properties of Columns tested by Razvi and Saatcioglu (1996a) ${ }^{[1]}$

\begin{tabular}{|c|c|c|c|c|c|c|c|c|c|c|}
\hline \multirow{2}{*}{ 龸罢 } & \multirow{2}{*}{ 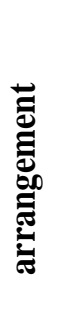 } & \multirow{2}{*}{ 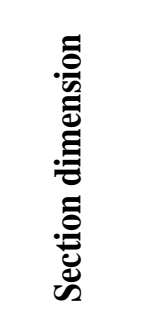 } & \multicolumn{2}{|c|}{$\begin{array}{c}\text { Longitudinal } \\
\text { Reinforceme } \\
\text { nt }\end{array}$} & \multirow{2}{*}{$\begin{array}{c}f_{c}^{l} \\
\sum_{\hat{z}}^{\sigma}\end{array}$} & \multirow{2}{*}{$\begin{array}{c}\boldsymbol{f}_{\text {y.long }} \\
\text { Мpa }\end{array}$} & \multirow{2}{*}{ 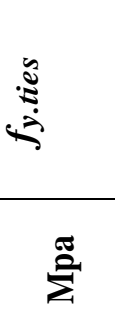 } & \multirow{2}{*}{ 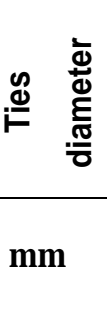 } & \multirow{2}{*}{$\begin{array}{c}\mathbf{s} \\
\mathrm{mm}\end{array}$} & \multirow{2}{*}{$\begin{array}{c}\rho \text { ties } \\
\%\end{array}$} \\
\hline & & & $\dot{0}$ & $\begin{array}{l}\text { Diam } \\
. \mathrm{mm}\end{array}$ & & & & & & \\
\hline CS-1 & 1 & $250 \times 250$ & 4 & 16 & 124 & 450 & 400 & 11.3 & 55 & 3.33 \\
\hline CS-2 & 2 & $250 \times 250$ & 8 & 16 & 124 & 450 & 570 & 6.5 & 55 & 2.16 \\
\hline CS-3 & 3 & $250 \times 250$ & 12 & 16 & 124 & 450 & 570 & 6.5 & 55 & 2.16 \\
\hline CS-4 & 2 & $250 \times 250$ & 8 & 16 & 124 & 450 & 1000 & 7.5 & 55 & 2.17 \\
\hline CS-5 & 3 & $250 \times 250$ & 12 & 16 & 124 & 450 & 1000 & 7.5 & 120 & 1.32 \\
\hline CS-8 & 2 & $250 \times 250$ & 8 & 16 & 124 & 450 & 400 & 11.3 & 85 & 3.24 \\
\hline CS-9 & 3 & $250 \times 250$ & 12 & 16 & 124 & 450 & 400 & 11.3 & 120 & 3.06 \\
\hline CS-11 & 1 & $250 \times 250$ & 4 & 16 & 81 & 450 & 400 & 11.3 & 40 & 4.59 \\
\hline CS-12 & 1 & $250 \times 250$ & 4 & 16 & 81 & 450 & 400 & 11.3 & 55 & 3.33 \\
\hline CS-13 & 2 & $250 \times 250$ & 8 & 16 & 92 & 450 & 570 & 6.5 & 55 & 2.16 \\
\hline CS-14 & 3 & $250 \times 250$ & 12 & 16 & 92 & 450 & 570 & 6.5 & 55 & 2.16 \\
\hline
\end{tabular}




\begin{tabular}{|c|c|c|c|c|c|c|c|c|c|c|}
\hline CS-15 & 2 & $250 \times 250$ & 8 & 16 & 81 & 450 & 1000 & 7.5 & 55 & 2.17 \\
\hline CS-16 & 3 & $250 \times 250$ & 12 & 16 & 81 & 450 & 1000 & 7.5 & 85 & 1.87 \\
\hline CS-18 & 3 & $250 \times 250$ & 12 & 16 & 81 & 450 & 400 & 6.5 & 85 & 1.4 \\
\hline CS-19 & 2 & $250 \times 250$ & 8 & 16 & 92 & 450 & 400 & 11.3 & 85 & 3.24 \\
\hline CS-20 & 3 & $250 \times 250$ & 12 & 16 & 92 & 450 & 400 & 11.3 & 85 & 4.32 \\
\hline CS-22 & 2 & $250 \times 250$ & 8 & 16 & 60 & 450 & 1000 & 7.5 & 85 & 1.4 \\
\hline CS-23 & 3 & $250 \times 250$ & 12 & 16 & 60 & 450 & 1000 & 7.5 & 120 & 1.32 \\
\hline CS-24 & 2 & $250 \times 250$ & 8 & 16 & 60 & 450 & 400 & 11.3 & 85 & 3.24 \\
\hline CS-25 & 3 & $250 \times 250$ & 12 & 16 & 60 & 450 & 400 & 11.3 & 120 & 3.06 \\
\hline
\end{tabular}

Notes : columns CS-2 and CS-13 had double layers of cross ties
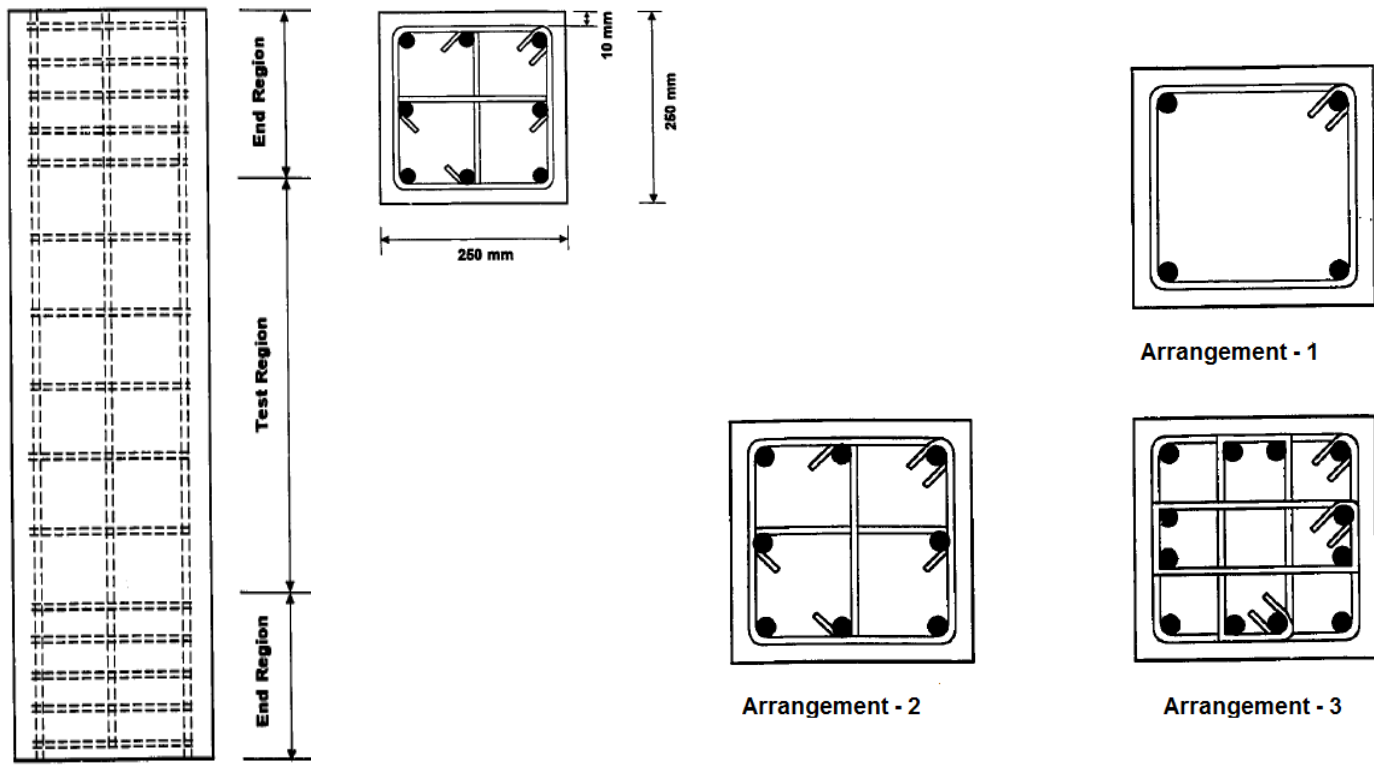

Arrangement - 1
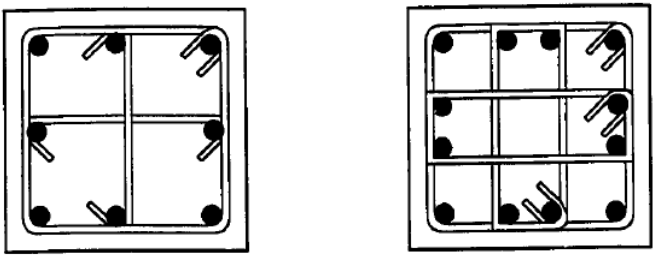

Arrangement - 2

Arrangement - 3

Fig. 2: Cross sectional arrangements and section geometry of columns tested by Razvi and Saatcioglu (1996a)

\subsection{Finite elements and numerical analysis}

In this study, ANSYS R15.0 Ref. (8) was used, which is capable of modeling the nonlinear behavior of reinforced concrete columns. Tested specimens in this investigation, and other specimens tested by other researchers are used for predicting the nonlinear behavior of well confined concrete columns with various compressive strength and various lateral reinforcement, under concentric load.

\subsubsection{Geometry Modeling}

In this study, nineteen normal strength concrete columns were tested experimentally with properties as shown above in table (1) and twenty high strength concrete columns tested experimentally by Razvi and Saatcioglu (1996a) with properties as shown above in table (2), were analyzed by ANSYS R.15.0 program. Where the main variables considered are concrete strength ranging from $39.5 \mathrm{Mpa}$ to $124 \mathrm{Mpa}$, and different confinement characteristics. 


\subsubsection{ANSYS Finite Element Model}

The FEA study included the modeling of reinforced concrete columns, along with the dimensions and properties corresponding to the actual experimental data. While the element type and material properties will be displayed in the following details to reflect the actual mechanical and physical properties of the column specimens

\subsubsection{Element Types}

\subsection{Concrete element}

Eight-node solid element, Solid65, was used to model the concrete. As shown below in Fig. 3 , the solid element has eight nodes with three degrees of freedom at each node - translations in the nodal $\mathrm{x}, \mathrm{y}$, and $\mathrm{z}$ directions. The element is capable of predicting plastic deformation, cracking and crushing in three orthogonal directions.

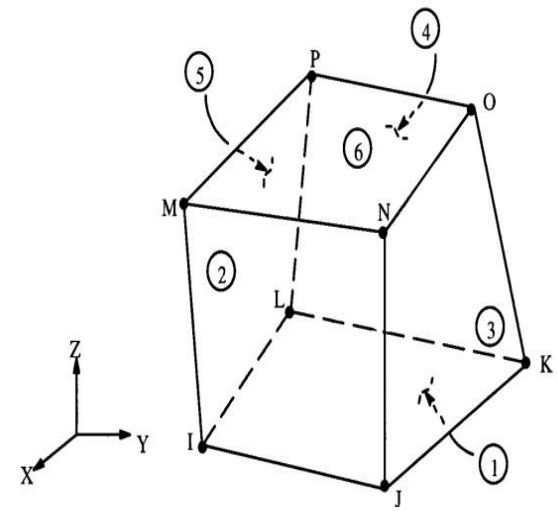

Fig.3: Solid65 -3D reinforced concrete solid

\subsection{Steel reinforcement}

Link180 element was used to model the steel reinforcement. Two nodes are required for this element, each node has three degrees of freedom, translations in the nodal $\mathrm{x}, \mathrm{y}$, and $\mathrm{z}$ directions. The element is also capable of modeling plastic deformation. The geometry and node locations for this element type are shown in figure (4)

Fig. 4 : Link 180 element type

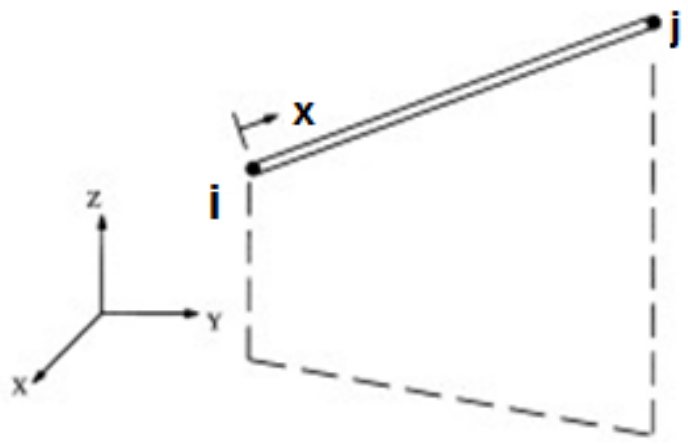

\subsubsection{Material Properties}

\subsection{Concrete}

Concrete is a brittle material and has different behavior in compression and tension. The stress strain curve relationship for concrete is described by multi- linear isotropic curve, linear elastic up to about 30 percent of the maximum compressive strength $\left(f_{c}^{\prime}\right)$. The stressstrain curve for each column model is constructed using points connected by straight lines to represent the multi-linear isotropic stress -strain curve for the concrete as shown in Fig. 5. For concrete, ANSYS R.15.0 requires input data for material properties as follows:

- Elastic modulus is the initial tangent slope of the stress strain curve of the concrete.

- Ultimate uniaxial compressive strength $\left(f_{c}^{*}\right)$, Poisson's ratio assumed to be 0.2 .

- Ultimate uniaxial tensile strength $\left(f_{z}\right.$, assumed to be $f_{z}=0.7\left(f_{c}^{\prime}\right)^{\wedge} 0.50$.

- Shear transfer coefficient $(\beta 0)$ for open cracks and $(\beta \mathrm{c})$ for closed cracks, representing Conditions of crack face for determining the amount of shear transfer across the crack were used. In present study, $(\beta 0)$ was assumed to be ranged from 0.20 up to 0.40 while $(\beta \mathrm{c})$ was assumed to be ranged from 0.60 up to 0.80 . 
Fig. 5: Simplified Uniaxial Compressive Stress-Strain Curve for concrete

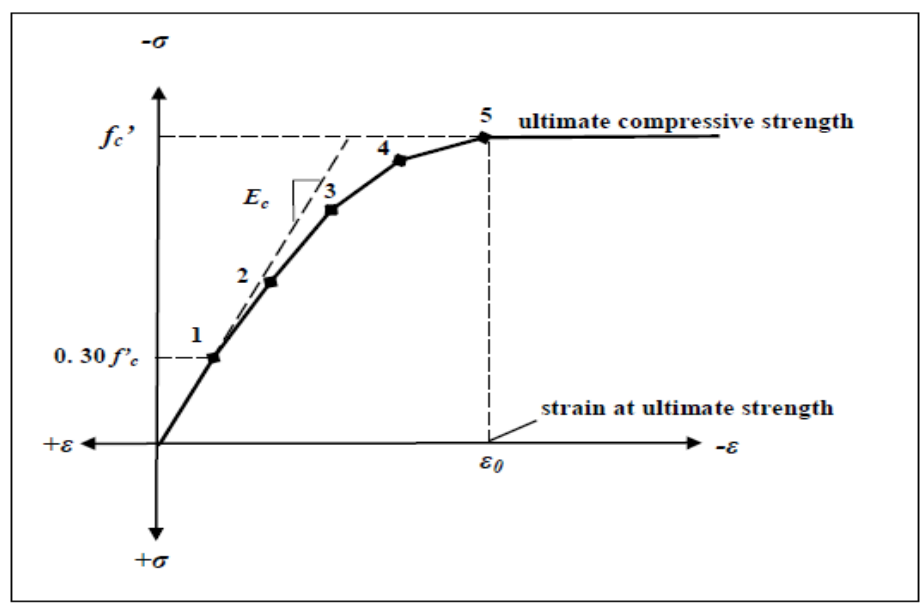

\subsection{Reinforcement}

An elastic modulus equal to $200,000 \mathrm{MPa}$ and Poisson's ratio of 0.3 were used for the longitudinal and transversal reinforcement, while the steel reinforcement was assumed to be linear isotropic elastic materials.

\subsubsection{Element Meshing}

After recording all the input data of material and geometrical properties, the column models were divided into small cubical or rectangular elements, as shown in Fig.6. For column specimens reinforced with longitudinal and transversal reinforcement, elements were created according to the location of reinforcing bars either the longitudinal or lateral reinforcement, as well as the column specimen cross - sectional perimeter. By using merge items in ANSYS, SOLID65 and Link180 elements can be interconnected one to another forming a single solid column model which is capable of simulating the actual behavior of reinforced concrete column.
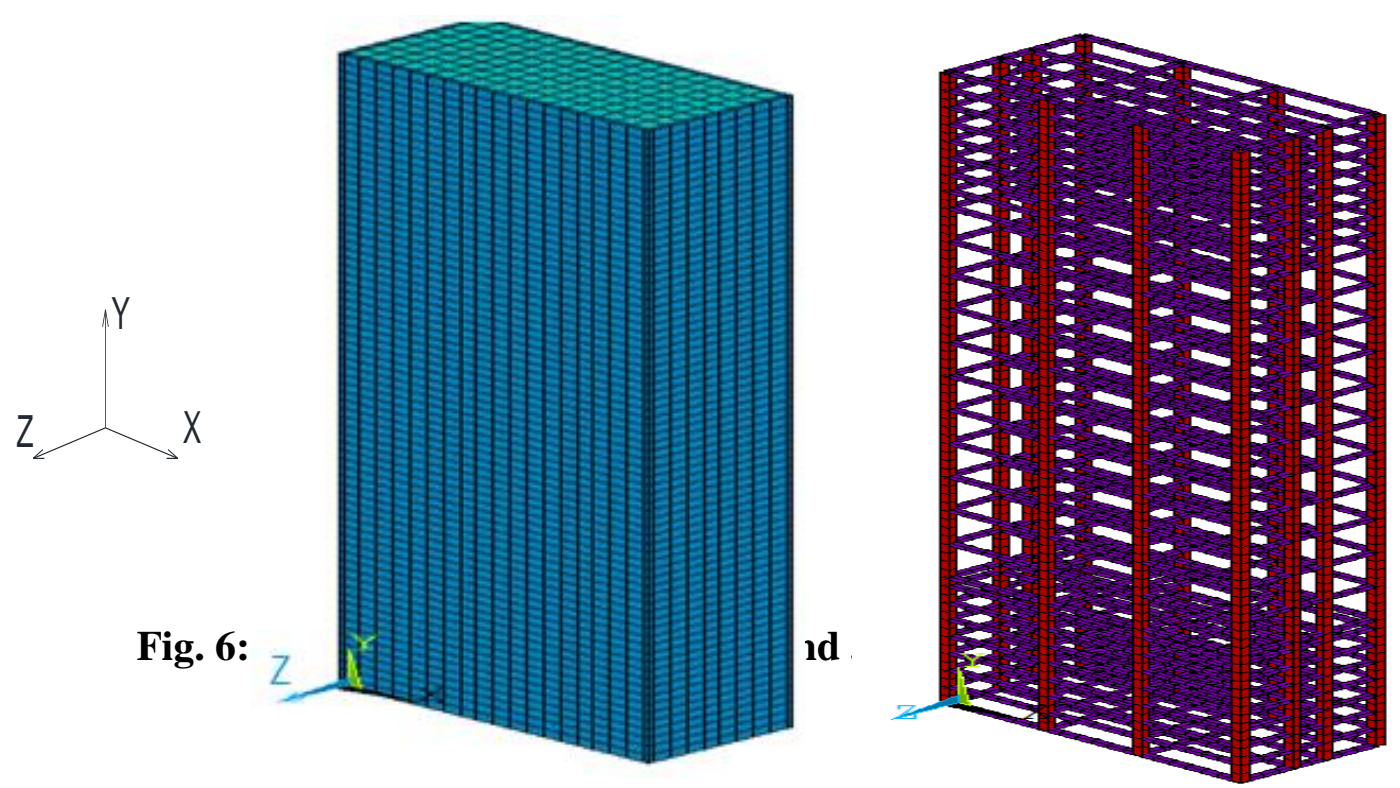

\subsubsection{Loads and Boundary conditions}

Displacement boundary conditions are needed to constrain the model to get a unique solution. To ensure that the model acts the same way as the experimental columns specimens, boundary conditions need to be applied where the supports and loadings exist.

For all columns models the displacement of all nodes at bottom base of column in y direction was held zero $(\mathrm{Uy}=0)$. To simulate the effect of the steel plate with $10 \mathrm{~mm}$ thickness and $300 \mathrm{~mm}$ height around the columns faces at the bottom and top of the column, the displacement of nodes at the columns faces which are parallel to X. direction was held zero 
in direction $\mathrm{Z}(\mathrm{Uz}=0)$ up to $300 \mathrm{~mm}$ height from the bottom and top faces of the column and the displacement of nodes at the columns faces which is parallel to Z . direction was held zero in direction $X(\mathrm{Ux}=0)$ up to $300 \mathrm{~mm}$ height from the bottom and top faces of the column.To apply the axial load on the top of the column specimens, an axial pressure was implemented over the entire top surface of the column model.

\subsubsection{Discussions}

In this study, it was found that if the crushing capability of the concrete is turned on, the finite element column models fail prematurely. Crushing of concrete started to develop in elements located outside the transverse reinforcement which is unconfined. Subsequently, adjacent concrete elements crushed within several load steps as well, significantly reducing the local stiffness. Finally, the solution diverged.

Therefore, in this study, the crushing capability was turned off for the unconfined elements. For the reinforced concrete columns the considered column area is the confined area up to the center line of transverse reinforcement. It is matching with the assumption that the peak load of the columns and maximum strength during experimental tests were carried by the confined area after spalling of concrete cover. The results of FEA give a good agreement with the experimental results.

The final load applied from finite element analysis, is the last load before the solution diverged. During this study, verification is carried out in order to check the validity and accuracy of the finite element procedure. The accuracy was determined by ensuring that axial force- axial strains relation-ship, axial stress distribution and maximum load is reasonably predicted compared with experimental results.

\subsubsection{Axial Force -Axial Strain Relationship}

The axial force-axial strain curves obtained from ANSYS solution $\left(\mathrm{P}_{\mathrm{y}}\right.$ and $\left.\varepsilon_{\mathrm{y}}\right)$ are compared with experimental results, as shown in Fig. 7, its shows that the predictions are in close agreement with experimental curves.

This indicates that the actual behavior of confined column specimens with transverse steel under concentric compressive loading can be accurately predicted by the F.E.A approach. The accuracy of the proposed procedure is also confirmed through the close value of compressive stress and compressive strain at maximum load, which is the final load from the finite element models of the last applied load before the solution diverged, compared with experimental results as shown in table (3) and table (4). These values show the accuracy of the proposed procedure in predicting the actual nonlinear behavior of columns. 

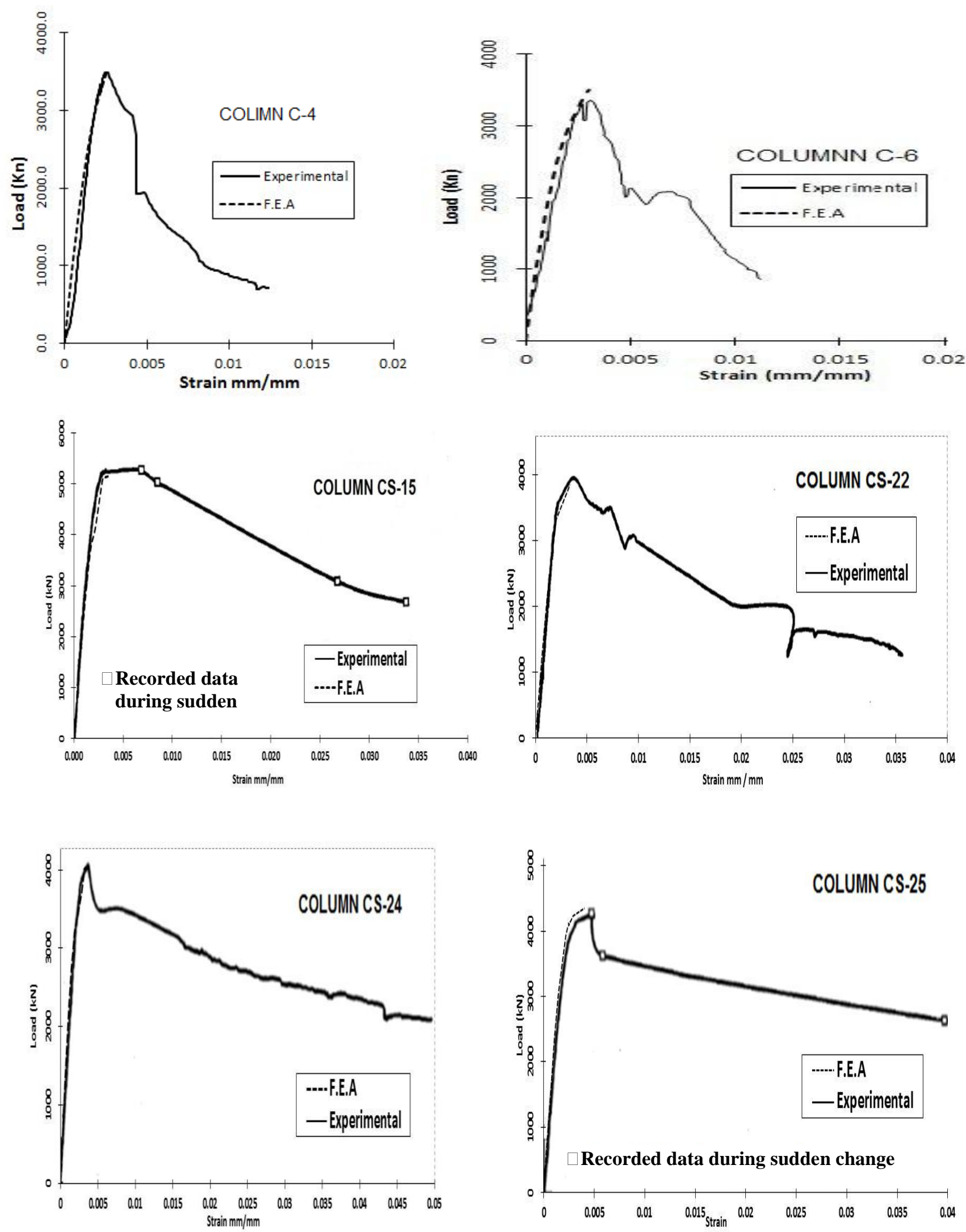

Fig. 7: Axial Force - Axial Strain Relationship for sample of Columns Comparison between the Experimental and finite element analysis 
NON LINEAR FINITE ELEMENT ANALYSIS FOR NORMAL AND HIGH STRENGTH CONCRETE COLUMNS CONFINED BY RECTANGULAR TIES

Table 3: Comparison between Experimental and F.E.A loads, stress and strain for the Rectangular Columns of present study

\begin{tabular}{|c|c|c|c|c|c|c|c|c|c|}
\hline \multirow[b]{2}{*}{$\begin{array}{c}\text { COLUMNS } \\
\text { LABEL }\end{array}$} & \multicolumn{3}{|c|}{ Experimental Results } & \multicolumn{3}{|c|}{ F.E.A Results } & \multicolumn{3}{|c|}{ F.E.A / Experimental } \\
\hline & $\begin{array}{l}\text { Max. } \\
\text { Load } \\
\text { (kn) }\end{array}$ & $\begin{array}{l}\text { Comp. } \\
\text { stress } \\
\text { (Mpa) }\end{array}$ & $\begin{array}{c}\text { Comp. } \\
\text { strain } \\
(\mathrm{mm} / \mathrm{mm})\end{array}$ & $\begin{array}{l}\text { Max. } \\
\text { Load } \\
\text { (kn) }\end{array}$ & $\begin{array}{l}\text { Comp. } \\
\text { stress } \\
\text { (Mpa) }\end{array}$ & $\begin{array}{c}\text { Comp. } \\
\text { strain } \\
(\mathrm{mm} / \mathrm{mm})\end{array}$ & $\begin{array}{l}\text { Max. } \\
\text { Load } \\
\text { (kn) }\end{array}$ & $\begin{array}{l}\text { Comp. } \\
\text { stress } \\
\text { (Mpa) }\end{array}$ & $\begin{array}{c}\text { Comp. } \\
\text { strain } \\
(\mathrm{mm} / \mathrm{mm})\end{array}$ \\
\hline $\mathrm{C}-1$ & 3602 & 56.30 & N.A & 3791 & 56.85 & 0.00301 & 1.05 & 1.01 & N.A \\
\hline $\mathrm{C}-2$ & 3670 & 57.36 & 0.00226 & 3399 & 52.00 & 0.00241 & 0.93 & 0.91 & 1.07 \\
\hline $\mathrm{C}-4$ & 3480 & 54.38 & 0.00240 & 3504 & 54.80 & 0.00263 & 1.01 & 1.01 & 1.10 \\
\hline$C-5$ & 3463 & 54.12 & 0.00330 & 3767 & 57.60 & 0.00299 & 1.09 & 1.06 & 0.91 \\
\hline$C-6$ & 3359 & 52.50 & 0.00310 & 3602 & 53.80 & 0.00300 & 1.07 & 1.02 & 0.97 \\
\hline $\mathrm{C}-7$ & 3232 & 50.52 & 0.00325 & 3439 & 51.98 & 0.00308 & 1.06 & 1.03 & 0.95 \\
\hline $\mathrm{C}-8$ & 3218 & 50.29 & 0.00303 & 3471 & 51.56 & 0.00275 & 1.08 & 1.03 & 0.91 \\
\hline $\mathrm{C}-9$ & 3408 & 53.26 & 0.00286 & 3551 & 52.03 & 0.00295 & 1.04 & 0.98 & 1.03 \\
\hline$C-10$ & 3318 & 51.85 & 0.00266 & 3277 & 54.15 & 0.00263 & 0.99 & 1.04 & 0.99 \\
\hline C -11 & 2857 & 61.06 & 0.00283 & 2875 & 61.51 & 0.00306 & 1.01 & 1.01 & 1.08 \\
\hline$C-12$ & 2733 & 58.42 & 0.00311 & 2609 & 54.37 & 0.00291 & 0.95 & 0.93 & 0.93 \\
\hline$C-13$ & 2999 & 64.1 & 0.00275 & 2938 & 59.64 & 0.00291 & 0.98 & 0.93 & 1.06 \\
\hline$C-14$ & 2777 & 59.36 & 0.00307 & 2737 & 55.68 & 0.00278 & 0.99 & 0.94 & 0.90 \\
\hline$C-15$ & 3258 & 69.64 & 0.00341 & 3242 & 63.4 & 0.00345 & 1.00 & 0.91 & 1.01 \\
\hline$C-16$ & 3120 & 66.69 & 0.00286 & 2936 & 62.51 & 0.00307 & 0.94 & 0.94 & 1.07 \\
\hline$C-17$ & 3183 & 68.04 & 0.00329 & 3263 & 64.70 & 0.00336 & 1.03 & 0.95 & 1.02 \\
\hline$C-18$ & 3014 & 64.42 & 0.00300 & 2815 & 58.60 & 0.00326 & 0.93 & 0.91 & 1.09 \\
\hline C -19 & 3037 & 64.92 & 0.00266 & 2938 & 59.70 & 0.00291 & 0.97 & 0.92 & 1.09 \\
\hline
\end{tabular}


NON LINEAR FINITE ELEMENT ANALYSIS FOR NORMAL AND HIGH STRENGTH CONCRETE COLUMNS CONFINED BY RECTANGULAR TIES

Table 4: Comparison between Experimental and F.E.A loads, stress and strain for the Square Columns tested by Razvi and Saatcioglu (1996a) [2]

\begin{tabular}{|c|c|c|c|c|c|c|c|c|c|}
\hline \multirow[b]{2}{*}{ 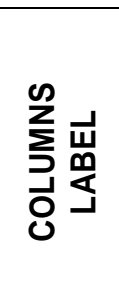 } & \multicolumn{3}{|c|}{ Experimental Results } & \multicolumn{3}{|c|}{ F.E.A Results } & \multicolumn{3}{|c|}{ F.E.A / Experimental } \\
\hline & $\begin{array}{l}\text { Max. } \\
\text { Load } \\
\text { (kn) }\end{array}$ & $\begin{array}{c}\text { Comp. } \\
\text { stress } \\
\mathbf{f}_{\text {test }} \\
\text { (Mpa) }\end{array}$ & $\begin{array}{c}\text { Comp. } \\
\text { strain } \\
(\mathrm{mm} / \mathrm{mm})\end{array}$ & $\begin{array}{l}\text { Max. } \\
\text { Load } \\
\text { (kn) }\end{array}$ & $\begin{array}{l}\text { Comp. } \\
\text { stress } \\
\text { (Mpa) }\end{array}$ & $\begin{array}{c}\text { Comp. } \\
\text { strain } \\
(\mathrm{mm} / \mathrm{mm})\end{array}$ & $\begin{array}{l}\text { Max. } \\
\text { Load } \\
\text { (kn) }\end{array}$ & $\begin{array}{l}\text { Comp. } \\
\text { stress } \\
\text { (Mpa) }\end{array}$ & $\begin{array}{c}\text { Comp. } \\
\text { strain } \\
(\mathrm{mm} / \mathrm{mm})\end{array}$ \\
\hline CS- 1 & 6040 & 126.28 & 0.0032 & 5979 & 130.91 & 0.00291 & 0.99 & 1.04 & 0.91 \\
\hline CS- 2 & 6597 & 132.07 & 0.0040 & 6974 & 131.6 & 0.00389 & 1.06 & 1.00 & 0.97 \\
\hline CS- 3 & 7218 & 144.50 & 0.0033 & 6950 & 130.78 & 0.00344 & 0.96 & 0.91 & 1.04 \\
\hline CS- 4 & 6631 & 133.94 & 0.0040 & 7005 & 132.63 & 0.00360 & 1.06 & 0.99 & 0.90 \\
\hline CS- 5 & 6849 & 138.35 & 0.0030 & 6885 & 128.21 & 0.00312 & 1.01 & 0.93 & 1.04 \\
\hline CS- 9 & 7177 & 150.05 & 0.0037 & 7292 & 139.81 & 0.00360 & 1.02 & 0.93 & 0.98 \\
\hline CS-11 & 4856 & 101.53 & 0.0033 & 4935 & 103 & 0.00349 & 1.02 & 1.01 & 1.06 \\
\hline CS-12 & 4366 & 91.28 & 0.0033 & 4400 & 90.18 & 0.00362 & 1.01 & 0.99 & 1.10 \\
\hline CS-13 & 4874 & 97.57 & 0.0067 & 5261 & 9493.94 & 0.00712 & 1.08 & 0.96 & 1.06 \\
\hline CS-14 & 5561 & 111.33 & 0.0030 & 5614 & 103.2 & 0.00287 & 1.01 & 0.93 & 0.96 \\
\hline CS-15 & 5296 & 106.98 & 0.0035 & 5282 & 101.87 & 0.00370 & 1.00 & 0.95 & 1.06 \\
\hline CS-16 & 5578 & 112.67 & 0.0033 & 5178 & 102 & 0.00335 & 0.93 & 0.91 & 1.01 \\
\hline CS-18 & 4713 & 94.35 & 0.0028 & 5170 & 87.95 & 0.00293 & 1.10 & 0.93 & 1.04 \\
\hline CS-19 & 5536 & 115.74 & 0.0048 & 5548 & 112 & 0.00464 & 1.00 & 0.97 & 0.97 \\
\hline CS-20 & 5911 & 123.58 & 0.0070 & 6461 & 117.39 & 0.00642 & 1.09 & 0.95 & 0.92 \\
\hline CS-22 & 3977 & 80.33 & 0.0035 & 3855 & 74.3 & 0.00333 & 0.97 & 0.92 & 0.95 \\
\hline CS-23 & 4437 & 89.63 & 0.0038 & 4291 & 82.5 & 0.00338 & 0.97 & 0.92 & 0.88 \\
\hline CS-24 & 4076 & 85.22 & 0.0035 & 4058 & 79.8 & 0.00349 & 1.00 & 0.94 & 0.98 \\
\hline CS-25 & 4246 & 88.77 & 0.0043 & 4351 & 82.94 & 0.00411 & 1.02 & 0.93 & 0.96 \\
\hline
\end{tabular}




\subsubsection{Stress Distribution}

The axial stress contours over mid-height cross sections of the columns specimens as shown in Fig. 8, indicated similar axial stress distributions with various intensities of stress concentrations. The stress diagram indicated that the axial stress concentrations increase around the longitudinal reinforcement laterally supported by the ties especially at the corners. As shown in Fig. 8 the stress distribution diagrams for the different specimens indicated that the shape of the pressure distribution is a function of reinforcement arrangement and resulting ties configuration ${ }^{[1]}$.
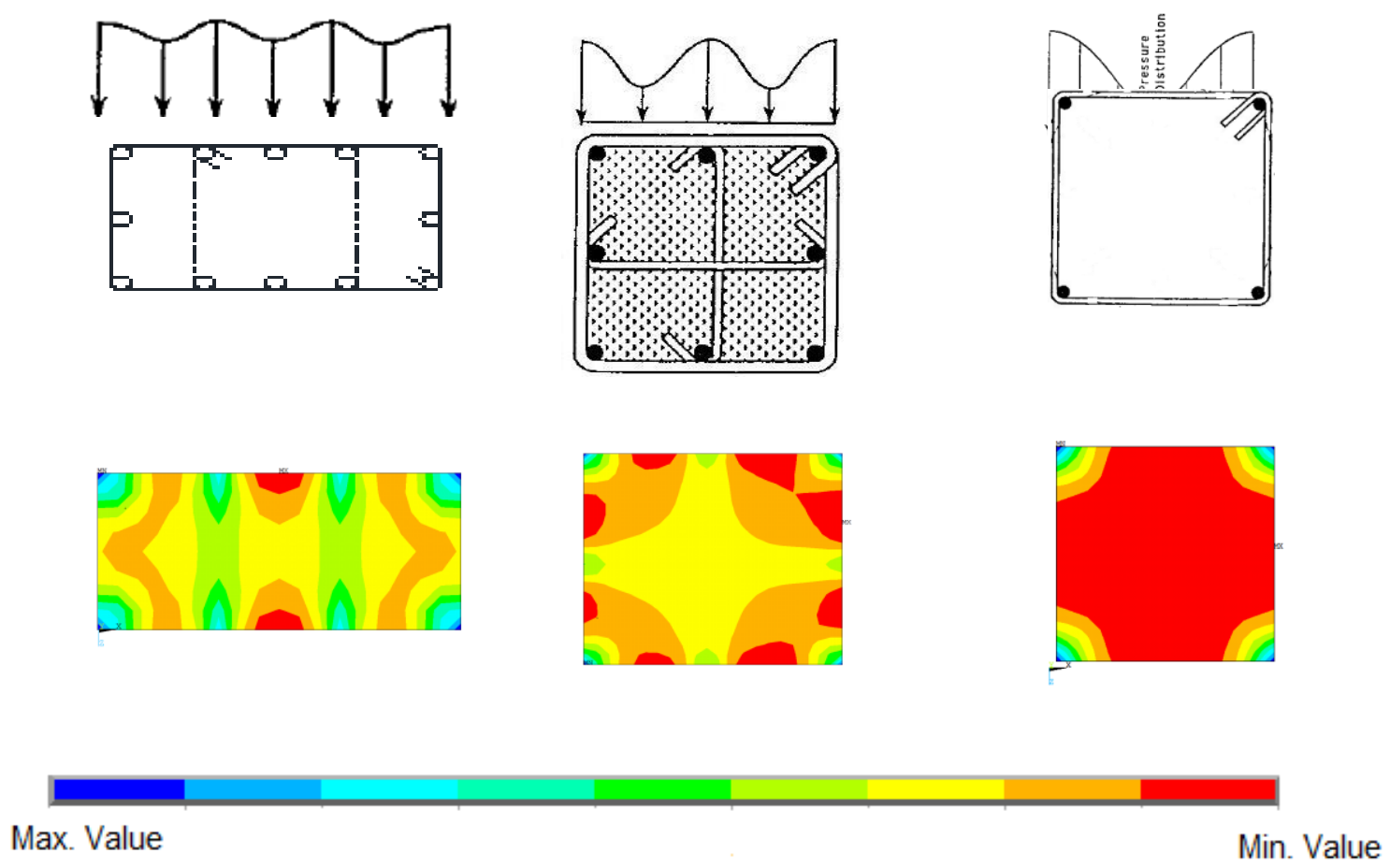

Fig 8: Axial Stress Contours of Confined Concentric Columns at Mid Height

\subsection{CONCLUSION}

Based on experimental programs and the finite element analysis and discussion above, the following conclusions can be drawn:

- ANSYS software is capable of predicting the actual behavior of normal and high strength reinforced concrete columns confined with rectangular ties under axial compressive loading, with different concrete dimensions, different concrete strength and different confinement characteristics.

- The accuracy of the proposed procedure has been well confirmed by the close value of maximum compressive load, compressive stress and compressive strain obtained from the F.E.A analysis which is ranging from $1 \%$ to $10 \%$ difference compared with the experimental results.

- From the axial stress contours obtained from the finite element analysis, the stress diagram indicates that the axial stress concentrations increase around the longitudinal reinforcement laterally supported by the ties especially at the corners. And the stress distribution diagrams for the different specimens indicate that the shape of the pressure distribution is a function of reinforcement arrangement and resulting ties configuration.

- Depending on this agreement between the experimental and analytical results, a parametric numerical study can be conducted by ANSYS 15 to clarify and evaluate the effect of confinement variables on strength and ductility of normal and high strength reinforced concrete columns confined with rectangular ties under axial compressive loading. 


\section{Notations}

$f^{\prime}$ oc : confined concrete compressive strength in member.

$f_{f, c o}^{\prime}$ : unconfined concrete compressive strength in member

$f_{c}=$ :Ultimate compressive strength concrete obtained from standard cylinder test

$\mathrm{f}_{\text {test }} \quad$ : Maximum Stress carried by concrete core as observed in test

fy.long : yield stress for the longitudinal reinforcement

fy.ties : yield stress for the transversal reinforcement

$P_{C . C}$ : Maximum load carried by core concrete

PF.A.A, : Maximum axial load carried by column as observed in ANSYS model.

$P_{\text {Test }}:$ Maximum axial load carried by column as observed in test

$S \quad$ : Spacing of transverse reinforcement in longitudinal direction.

$\rho \quad$ : Volumetric ratio of transverse reinforcement, defined as volume of transverse Steel divided by volume of concrete.

\section{REFERENCES}

[1]. Razvi, S.R., "Confinement of Normal and High-Strength Concrete Columns." Ph.D. Dissertation, Department of Civil Engineering, the University of Ottawa, Ottawa, Ontario, Canada,1995, p. 99-124.

[2]. Saatcioglu, M. and Razvi, S., "High-Strength Concrete Column with Square section under Concentric Compression". Journal of Structural Engineering, @ ASCE, MARCH 1999, p. 281-289.

[3]. Karabinis. A. I, and Kiousis, P. D., "Strength and Ductility of Rectangular Concrete Columns A Plasticity Approach", J. Structural Engineering ASCE, Vol. 122, No. 3, p. 267 274 March, 1996.

[4]. P. Paultre, and F. Legreon, "Confinement Reinforcement Design for Reinforced Concrete Columns." Journal of Structural Engineering@ ASCE, MAY 2008, p. 738-749.

[5]. Harba, Ibrahim, "Non Linear Finite Element Analysis of Confined HSC Columns under Concentric and Eccentric Loadings." Journal of Engineering and Development, Vol. 16, No.3, Sep. 2012 ISSN 1813- 7822

[6]. M. Saatcioglu, P. Paultre and S.K. Ghosh "Confinement of High Strength Concrete." SP 176-6, p. 105-136.

[7]. Mander, J. B., Priestley, M. J. N., and Park R., "Theoretical Stress-Strain Model for Confined Concrete," Journal of the Structural Engineering, ASCE, Vol. 114, No. 8, August 1988, p. 1804-1826.

[8]. ANSYS, ANSYS User's Manual Revision, ANSYS, INC., Canonsburg, Pennsylvania. 